\title{
Agnieszka Gronkowska-Koziar*
}

\section{Wychowanie patriotyczne w posłudze duszpasterskiej kardynała Stefana Wyszyńskiego \\ Patriotic Education in the Pastoral Activity of Cardinal Stefan Wyszyński}

\begin{abstract}
The aim of the publication was to bring out the specificity of the views of Cardinal Stefan Wyszyński on the patriotic education of children and youth from his manifold pastoral ministry activity. The first part of the publication presents the primate's understanding of the phenomenon of patriotism itself. By introducing and presenting Wyszyński's views, author indicated the essential elements constituting patriotism. This patriotism is seen in several categories: axiological (desired value), psychological (attitude) as well as action-oriented (upbringing). Second part of the publication is devoted to responsible patriotic education of children and youth. The performed research not only deepened the understanding of this significant issue, but also enabled generalization in the form of conclusions and summaries.

Author determined that, according to the views of Stefan Wyszyński, patriotism is a precious value in life of every human being, and it should be perceived as a duty rather than a privilege. This duty is aimed at loving one's homeland and shaping a sense of national identity. Wyszyński calls for taking the responsibility for the process of patriotic education. This education should, in his view, emphasize cultivation of native language, respect of national heritage, guardianship of truth, and transmission of an unadulterated history. The essential tasks, expressing one's obligation to take responsibility for one's country, are protecting life of each citizen (including unborn children), and defend-
\end{abstract}

* Agnieszka Gronkowska-Koziar (ORCID: oooo-0oo3-1037-6493) - mgr, doktorantka w Instytucie Pedagogiki (Katedra Dydaktyki, Edukacji Szkolnej i Pedeutologii) Katolickiego Uniwersytetu Lubelskiego Jana Pawła II, kontakt: agronkowska92@interia.pl. 
ing national and Christian values. Author of the publication realizes that the primate's understanding of both patriotism and education was influenced not only by his personal experience at home and school, but also by his anthropological views, abundant socio-historical knowledge, judgment skills, and pedagogical experience. This understanding was far from nationalism or intolerance. It sprang out of faithfulness to God, man, and centuries-old Christian tradition and culture. It guaranteed the pursuit of truth, freedom, respect for human rights, righteousness in thought and action, identity and existence of the nation.

Keywords: Cardinal Stefan Wyszyński, patriotism, homeland, nation, patriotic education, pastoral activity.

\section{Wstęp}

W

ychowanie patriotyczne współczesnego pokolenia młodych ludzi jest istotną płaszczyzną działalności edukacyjnej realizowaną nie tylko w środowisku rodzinnym, przedszkolnym, szkolnym, kościelnym czy też pozaszkolnym. Niestety problematyka wychowania patriotycznego dla wielu współczesnych rodziców i wychowawców to rzeczywistość zapomniana, nieznana, a niekiedy świadomie wypaczana. Osłabienie zainteresowania patriotyzmem, brak więzi społecznych, obniżenie etyki życia społecznego i politycznego oraz świadomości Polaków na temat kultury narodowej i przywiązania do rodzimej tradycji staje się wyrazem współczesnych trendów, gdzie propaguje się wychowanie oderwane od takich zagadnień jak: patriotyzm, ojczyzna, naród, język, religia czy też dziedzictwo kultury narodowej. Wiedza o własnej ojczyźnie, potrzeba uczuciowego wiązania dzieci i młodzieży z narodem i jego historią, a także wskazywanie na konieczność podejmowania odpowiedzialnych działań na rzecz własnego narodu to kluczowe elementy wychowania patriotycznego, o których niejednokrotnie w swojej posłudze duszpasterskiej zabiegał błogosławiony Stefan Wyszyński.

Mając świadomość wagi problemu, jakim jest dziś właściwie pojęte wychowanie patriotyczne w niniejszym artykule chcę, choćby tylko przyczynkarsko, przywołać i zaprezentować warte zapoznania nauczanie Prymasa Tysiąclecia dotyczące tej kwestii. W jego nauczaniu zagadnienie ojczyzny i narodu należą do podstawowych elementów wychowania patriotycznego i społecznego. Nie- 
jednokrotnie kwestie te podejmują autorzy ${ }^{1}$ publikacji i opracowań inspirujący się bogatą twórczością i działalnością kardynała Stefana Wyszyńskiego.

\section{Rozumienie patriotyzmu przez Kardynała Stefana Wyszyńskiego}

Gdy analizujemy bogate nauczanie prymasa Stefana Wyszyńskiego, nasuwa się spostrzeżenie, że na każdym etapie swojej posługi przywiązywał wielką wagę do miłości ojczyzny i stale ją propagował. Będąc autorytetem moralnym, nie ukrywał swojej miłości do Polski, a czynił to w czasach, kiedy tylko pozornie nasza ojczyzna była wolna. Potwierdzają to słowa, w których wyznaje: „Kocham ojczyznę więcej niż własne serce i wszystko, co czynię dla Kościoła, czynię dla niej"2. Polska była dla niego ojczyzną, dla której warto było żyć dobrze, narodem, który ma być silny wiarą i pamięcią, o tych, którzy oddali za nią życie³.

Gdy myślimy o patriotyzmie w ujęciu kardynała Stefana Wyszyńskiego, należy w pierwszej kolejności zwrócić uwagę na jego genezę, podstawowe założenia oraz cele. W jednej ze swoich ostatnich publikacji Alina Rynio zwraca uwagę, że „Wyszyński najczęściej łączył pojęcie patriotyzmu z emocjonalną postawą więzi z własnym narodem i jego historią, a także duchową przynależnością do wspólnoty tworzącej ojczyznę w przeszłości, teraźniejszości i przyszłości”"4.

1 A. Rynio, Mądre wychowanie patriotyczne przedmiotem troski Prymasa Tysiąclecia, „Studia Prymasowskie”, 5 (2011), s. 247-264; Taż, Myśl pedagogiczna Stefana Kardynała Wyszyńskiego, w: Kardynat Stefan Wyszyński (1901-1981) Myśl spoteczna , red. S. Fel, M. Wódka, Lublin 2017, s. 47-70; taż, Idea Narodu i odpowiedzialności za naród w kazaniach milenijnych czcigodnego Sługi Bożego Kardynała Stefana Wyszyńskiego, Lublin 2020. C. Bartnik, Pedagogika narodowa Prymasa Stefana Wyszyńskiego, Lublin 2001; tenże, Pedagogika narodowa Prymasa Stefana Wyszyńskiego, Lublin 2001; M. B. Stępien, Kościót i Naród jako wartości fundamentalne, w: Prymas Tysiąclecia w komunistycznym państwie, red. Z. Zieliński, Radom 2003, s. 9-31.

2 Kardynał Stefan Wyszyński Kruszwica, Kościót śś Piotra i Pawła, 18 września 1970.

3 Por. A. Gronkowska, Po Bogu Polska była dla Niego... w: Spoteczna potrzeba pamięci. Osoba i dzieło kardynała Stefana Wyszyńskiego Prymasa Tysiąclecia, red. A. Rynio, M. Parzyszek, Lublin 2017, s. 359-362.

4 A. Rynio, Wychowanie patriotyczne w nauczaniu Stugi Bożego Kardynała Stefana Wyszyńskiego, w: Prymas Wyszyński a Niepodległa: naród - patriotyzm - państwo w nauczaniu Prymasa Tysiąclecia, red. Ewa K. Czaczkowska, Rafał Łatka, Warszawa 2019, s. 106. 
Więź ta łączyła się z osobami należącymi do ojczyzny, z którymi się wzrastało w rodzinie, szkole, w najbliższym środowisku, łączyła się z przyrodą, z ważnymi miejscami w ojczyźnie, z ojczystą literaturą, sztuką i architekturą, a także z dziełami malarstwa i muzyki. Patriotyzm, miłość ojczyzny, w ujęciu prymasa, nie jest tylko sprawą uczucia czy emocji. Wiąże się on ze sferą życia emocjonalnego człowieka, ale się do niej nie ogranicza i wyraźnie ją przekracza. Dzieje się tak za sprawą tego, że Stefan Wyszyński wyprowadza patriotyzm z dziejów narodu, z jego kultury i tradycji, dla których źródłem jest chrześcijaństwo ${ }^{5}$. Ponadto cytowana wyżej autorka podkreśla, iż „prymasowskie rozumienie patriotyzmu utożsamiane było z szeroko rozumianą postawą miłości obejmującej Boga, człowieka i ojczyznę i dlatego należałoby ujmować je w i działaniowych"6. Przedmiotem postawy patriotycznej według Stefana Wyszyńskiego jest więc miłości do ojczyzny w jej wymiarze przestrzennym, wspólnotowym i kulturowym. Warto przy tym dodać, iż prymasowski patriotyzm bierze swój początek z miłości i czci dla rodziców i rodziny. Przejawia się jako powinność moralna oraz zespół cnót obywatelskich. Jest on pozbawiony egoistycznej dumy z tego powodu, że jest się Polakiem czy przedstawicielem innego narodu. Charakteryzuje się raczej zespołem cnót społecznych łączących się z umiejętnością okazywania czci, jaką człowiek powinien mieć dla tej społeczności, która go wychowała, tj. rodziny, państwa, Kościoła i narodu?

Miłość do ojczyzny rozumiana i propagowana przez Stefana Wyszyńskiego wiązała się z naturalnym obowiązkiem każdego człowieka na miarę czasów, w których przyszło mu żyć. Prymas Tysiąclecia podkreślał, że „człowiek w narodzie żyje nie tylko dla siebie i nie tylko dziś, ale także w wymiarze dziejów naro$\mathrm{du}^{\prime \prime}$. Odwoływał się do polskiej historii, tradycji, do zdrowego rozsądku, nawoływał postanowień „Porozumienia” z 1950 r., jakie zawarł w imieniu episkopatu z ówczesnym rządem i przestrzegał przed naśladowaniem wrogich Polsce i jakże destruktywnych wzorów radzieckich. „Zachęta do odważnego patrzenia w przyszłość, roztropnego osądu rzeczywistości i ambicji trwania ku przyszłości - sta-

5 Tamże.

6 Tamże, s.107.

7 Tamże.

8 Cyt. za: B. Piasecki, Ostatnie dni Prymasa Tysiąclecia, Kraków 2011, s. 10-11. 
nowiła podstawę do budowania mocnego narodu polskiego" ${ }^{\prime}$, przywiązanego do wielowiekowej tradycji chrześcijańskiej i własnej tożsamości. Dlatego też wielokrotnie powtarzał: „Naród bez dziejów, bez historii, bez przeszłości, staje się wkrótce narodem bez ziemi, narodem bezdomnym, bez przyszłości"10.

Miłość ziemi ojczystej była przez kardynała podkreślana wielokrotnie. Czynił to na każdym etapie swego życia i posługi pasterskiej ${ }^{11}$. Wskazywał na ojczyznę wolną i suwerenną, w której powinna być gwarantowana wolność i niezależność Kościoła. Stanowisko to nie było jednak podzielane przez ówczesne władze, które dążyły do ustanowienia w Polsce kościoła państwowego. W związku z tym 9 lutego 1953 r. władze państwowe wydały dekret o obsadzaniu stanowisk kościelnych od wikariusza parafialnego po biskupa we wszystkich diecezjach i natychmiast wprowadziły go w życie. Przeciw temu stanowczo zaprotestowali prymas Wyszyński i inni biskupi. W konsekwencji słynne prymasowskie non possumus doprowadziło do tego, że w nocy z 24 na 25 września 1953 r. decyzją Biura Politycznego Komitetu Centralnego Polskiej Zjednoczonej Partii Robotniczej, został aresztowany i uwięziony na trzy lata. Przebywał najpierw w Rywałdzie, następnie w Stoczku Warmińskim, Prudniku Śląskim oraz w Komańczy ${ }^{12}$. W czasie odosobnienia dał świadectwo silnej wiary i odpowiedzialności za losy Kościoła, narodu i ojczyzny. Mimo że na różne sposoby próbowano go złamać, ostatecznie stał się symbolem niezłomności wobec systemu komunistycznego. Doświadczenia życiowe Stefana Wyszyńskiego wzmocniły jego szacunek dla drugiego człowieka oraz umiłowanie ojczyzny. Wskazywał, że

Poświęcenie się za ojczyznę jest znakiem zrozumienia naszego miejsca w niej, a także użyteczności tej ofiary oraz doniosłości jej dla całej ojczy-

9 A. Jasiński, Kardynał Stefan Wyszyński świadek wiary, cz. 1. Gniezno 1999, s. 81.

10 Kardynał Stefan Wyszyński, Kruszwica, Kościół śs. Piotra i Pawła, 18 września 1970; Cyt. za: Niezwykły gość. Ksiądz Stefan Wyszyński u Aleksandra i Jadwigi Zamoyskich w Kozłówce, Muzeum Zamoyskich w Kozłówce 2021, s. 5.

11 Dobitnie ukazują to publikacje o charakterze biograficznym, których jest bardzo dużo. Przykładem mogą być: Kardynał Stefan Wyszyński. Drogi życia i posługi pasterskiej, red. R. Czekalski, Warszawa 2021; Niezwykły gość; Z. J. Kijas, Wyszyński. Narodziny nowego człowieka, Warszawa 2021.

12 A. M. Kowalczyk, Ethos Katolickiego Uniwersytetu Lubelskiego w wypowiedziach Kardynała, w: Społeczna potrzeba pamięci. Osoba i dzieło kardynała Stefana Wyszyńskiego..., S. 283. 
zny i każdego z nas. Chociażby poświęcenie okazało się w pierwszym momencie nieskuteczne, zawsze jednak świadczy ono o wyższości ludzi nad wszystkimi sprawami tej ziemi, dzięki gotowości człowieka do przezwyciężania siebie ${ }^{13}$.

Postawą manifestującą patriotyzm, który nie tyle jest „przywilejem co powinnością, jest szeroko rozumiana odpowiedzialność za ojczyznę i wszystko, co ją stanowi. Według Rynio w nauczaniu prymasa stanowi ją

naród, kultura, religia, wychowanie, tożsamość, dziedzictwo umiłowania ojczystej ziemi, wolności i solidarności, ład moralny i społeczny, historia zwycięskich i przegranych powstań narodowych i bitew, cierpienie, pamięć o bohaterach, współpraca i pokój, godność pracy ludzkiej, ochrona rodziny i życia nienarodzonych, wzory osobowe, troska o to, co aktualnie dzieje się w ojczyźnie, umiłowanie Matki Bożej. Wszystko to znajduje swój wyraz nie tyle w jego słowach ile w konkretnych czynach i działaniach ${ }^{14}$.

Prymasowski patriotyzm, podobnie jak inne postawy, jest strukturą nabytą. Pojawia się w osobowości człowieka jako efekt interakcji z jej własnym środowiskiem społecznym a więc z rodziną, szkołą, Kościołem, udziałem w organizacjach pozaszkolnych i kulturowym.

\section{Odpowiedzialne wychowanie patriotyczne młodych pokoleń}

Szczególną rolę w nabywaniu postawy patriotycznej od najmłodszych lat odgrywa wychowanie, w którym istnieje przekaz istotnych, rodzimych wartości kultury, norm moralnych, wzorców zachowań i działalności społecznej. W rozumieniu Stefana Wyszyńskiego wychowanie patriotyczne dzieci i młodzieży jest jedną z dziedzin wychowania integralnego, obejmującego wszelkie zamierzone oddziaływania na wychowanka, podejmowane w określonej sytuacji, celem wspomagania go w wielkodusznym i wiernym rozwijaniu praw-

13 S. Wyszyński, Jedna jest Polska, s. 28.

14 A. Rynio, Wychowanie patriotyczne w nauczaniu Sługi Bożego Kardynała Stefana Wyszyńskiego, w: Prymas Wyszyński a Niepodległa: naród - patriotyzm - państwo..., s. 115 . 
dziwej i czynnej miłości ojczyzny z równoczesnym kształtowaniem właściwie rozumianej tolerancji wobec innych narodów i kultur. Wiąże się to z wysiłkiem poznawania i miłowania kultury narodowej i jej wartości duchowych, formowania charakteru zgodnie z zasadami porządkującymi życie ojczyzny, tworzenia dziedzictwa kulturowego, pomnażania go i przyjmowania za niego odpowiedzialności, tak aby to dziedzictwo mogło być przekazywane następnym pokoleniom. Wyszyński jako wychowawca chciał być blisko tych, których nauczał, pragnął ich wzrostu oraz szanował ich wolność. Od początku jego działalności duszpasterskiej i pisarskiej widoczny był wysiłek zmierzający do zrozumienia świata młodzieży ${ }^{15}$. Jak zauważa Rynio „Wychowanie patriotyczne Wyszyńskiego, wiązało się z wychowaniem do poczucia odpowiedzialności za naród i tym wszystkim, co konstytuuje jego wartość. Wychowanie w poczuciu odpowiedzialności za naród Wyszyński upatrywał w wychowaniu młodego człowieka do wszechstronnego rozwoju osobowości"16. Co więcej, w myśli Kardynała Stefana Wyszyńskiego wychowanie do odpowiedzialności za naród, „przynależy do zasadniczych celów patriotycznego wychowania młodych na ludzi rozsądnych, wartościowych obywateli i prawych chrześcijan, myślących po polsku. Cele te osiąga się na drodze wychowania w wierności tradycji chrześcijańskiej i kulturze narodowej"17. Ponadto w nauczaniu Wyszyńskiego wychowanie młodego pokolenia w poczuciu odpowiedzialności za naród opierało się więc na obowiązku poznania i zachowania ewangelicznych zasad w życiu społecznym. Obowiązek ten stanowił konsekwencję bycia chrześcijaninem i wiązał się, więc z odpowiedzialnością za wiarę i kulturę narodu ${ }^{18}$.

Wychowanie w duchu odpowiedzialności za naród i przyszłość całego społeczeństwa wiązało się również z przygotowaniem młodzieży do przyszłego życia rodzinnego i zawodowego. Ukazując potrzebę wychowania w odpowiedzialności za naród, Wyszyński wzywał do ducha ofiary i wyrzeczenia, bez których

15 Por. Ojciec Święty Jan Paweł II o Kardynale Stefanie Wyszyńskim, w: Człowiek niezwyktej miary, Warszawa 1984, s. 127-140.

16 A. Rynio, Wychowanie patriotyczne w nauczaniu Sługi Bożego Kardynała Stefana Wyszyńskiego, s.114.

17 Tamże.

18 Tamże. 
nie można mówić o dobrym spełnieniu obowiązków, zachęcał do pokonywania samolubstwa, egoizmu i wygodnictwa.

Według prymasa Wyszyńskiego odpowiedzialne wychowanie patriotyczne powinno zaczynać się w domu i obejmować wychowanie umysłu, wyobraźni, uczuć i woli. W swoich kazaniach, listach i okolicznościowych przemówieniach podkreślał znaczenie wychowania w duchu obrony narodowych tradycji i kultury oraz historii. Szczególną uwagę przywiązywał do wychowania rodzinnego i zabiegał o to, aby w rodzinach uczono szacunku do języka ojczystego, literatury, sztuki, etyki oraz religiii19. Podkreślał, że kultura wyznacza tożsamość każdego człowieka. Dlatego też zarówno wychowanie patriotyczne w rodzinie, jak i w innych środowiskach wychowujących powinno wiązać się z kształtowaniem wrażliwości na kulturę. Początkiem takiego wychowania jest chociażby ukazywanie dziejów i kultury kraju ojczystego, piękna jego krajobrazu, bogactw naturalnych, cmentarzy i grobów, symboli narodowych czy piękna mowy ojczystej. Środkami wzbogacającymi przekazywanie dzieciom i młodzieży wiedzy o Polsce są zaś literatura piękna, architektura, szeroko rozumiana sztuka i kultura artystyczna, tradycje, uroczystości narodowe, wytworzone i kultywowane przez rodzinę obyczaje, odpowiednia atmosfera domu i niczym niezastąpione przykłady najbliższych ${ }^{20}$.

Jak wskazuje Magdalena Parzyszek, odpowiedzialne wychowanie patriotyczne w ujęciu Stefana Wyszyńskiego to przygotowanie dzieci do przyszłych zadań społecznych i obywatelskich. Prymasa pisał bowiem: „Rodzina ma w najlepszy sposób przygotować dzieci do zadań społecznych i do obywatelskich powinności" ${ }^{21}$. Wychowanie patriotyczne w rodzinie powinno opierać się na wartościach chrześcijańskich, zdrowym pielęgnowaniu wartości narodowych i kształtowaniu cnót obywatelskich. Także szkoła, Kościół i organizacje pozaszkolne mają wiele do zrobienia w tym względzie.

Podsumowując ten wątek analiz, należy podkreślić, iż miłość do ojczyzny kardynał Wyszyński uważał za naturalny obowiązek każdego Polaka, a patriotyzmu nie utożsamiał z szowinizmem czy błędnym nacjonalizmem. Pozosta-

19 S. Kowalczyk, Personalizm społeczno-aksjologiczny Kardynała Stefana Wyszyńskiego, w: Społeczna potrzeba pamięci..., S. 128.

20 A. Rynio, Mądre wychowanie patriotyczne... s. 262-263.

21 Cyt. za: M. Parzyszek, Rodzina w nauczaniu Stefana Wyszyńskiego, w: Społeczna potrzeba pamięci..., s. 226. 
wił też wiele praktycznych wskazówek, jak dzisiaj należy kochać ojczyznę. Uważał, że nie tyle potrzeba nam dziś bohaterskiej śmierci z miłości do ojczyzny, ile bohaterskiej pracy dla niej. Mówił: „My jesteśmy znani z tego, że musimy się poświęcić i życie oddać. Polacy potrafią wspaniale umierać, ale najmilsi, potrzeba, aby Polacy umieli wspaniale pracowaćm ${ }^{22}$.

\section{Prymasowski program odnowy narodu w duchu patriotyzmu}

Zaangażowany w sprawy Kościoła i Polski prymas Wyszyński dążył do dobra, przebaczenia nieprzyjaciołom i budzenia głębokiej wiary w Boga, troszcząc się o takie wychowanie patriotyczne, które by nie tylko uświadamiało prawa, ale i obowiązki względem ojczyzny, Kościoła, samego siebie i drugiego człowieka. Tak rozumiany patriotyzm został w nim ukształtowany pod wpływem wychowania w domu rodzinnym i edukacji, jaką otrzymał, zaczynając od szkoły podstawowej przez gimnazjum, seminarium duchowne, a kończąc na Katolickim Uniwersytecie Lubelskim. Istotny był tu też wpływ różnych środowisk, z którymi się stykał od swojej młodości. Były to m.in.: harcerstwo, środowisko „Odrodzenia", robotników z Włocławka, księży z konwiktu, środowisko ziemiańskie, społeczność pensjonariuszy i opiekunów zakładu dla niewidomych z podwarszawskich Lasek czy środowisko kobiet z IPP. Swój zmysł patriotyczny potrafił rozwijać pod wpływem spotkań z ludźmi prostymi, doświadczeń ludzkich dramatów, jakich był świadkiem w czasie wojny, a także, spotkań z ludźmi nieprzeciętnymi. Byli wśród nich m.in.: ks. Antonii Bogdański, Władysław Korniłowicz, ks. Antoni Szymański, Matka Elżbieta Róża Czacka, kard. August Hlond czy papieże XX wieku, nie mówiąc o postaciach historycznych.

Prymasowskie rozumienie patriotyzmu warunkowane było nie tylko doświadczeniem osobistym, ale przyjmowaną antropologią i rozległą wiedzą socjologiczno-historyczną. W jego rozumieniu człowiek to konkretna osoba, posiadająca przymioty rozumności, wolności, godności, niezbywalne prawa, żyjąca w rodzinie i pracująca w narodzie ${ }^{23}$. Godność osoby jest najwyższą

22 Cyt. za: A. Rastawicka, Maryjne drogi wolności Prymasa Tysiąclecia. Czytania majowe, Warszawa 2018, s. 65. Głupio jest cytować prymasa z drugiej ręki, czy ma może Pani dostęp do tych prac, aby sprawdzić, skąd Magda i Rastawicka wzięly te cytaty?

23 Stefan Kardynał Wyszyński, Do Polaków i Polonii, Warszawa 2020, s. s. 41. 
wartością, wyklucza przedmiotowe traktowanie samego siebie i innych, nadaje treść fundamentalnej normie moralnej, jaką jest miłośćc ${ }^{24}$. W nauczaniu i posłudze duszpasterskiej Prymasa człowiek jest rozpatrywany jako compositum jedności duszy i ciała ${ }^{25}$, rozumu i serca, prawa i sumienia. Jako ktoś, kto został stworzony na obraz i podobieństwo Boże - jako istota rozumna i wolna ${ }^{26}$.

Przy różnych okazjach prymas apelował, by nie pogrążać się w utylitarnym indywidualizmie czy nacjonalizmie. W swoich kazaniach nawoływał, aby ludzie się odmienili i społecznie miłowali. Uczył, że ten przegrywa, kto nie miłuje. Przestrzegał przed ateizmem, indywidualizmem, kolektywizmem i nadużyciami władzy cywilnej. Zabiegał o odnowę moralną całego narodu. Uważał, że jest to możliwe poprzez należyte wychowanie młodzieży i odnowę ludzkich sumień. Wskazywał przy tym na ład religijny i moralny obowiązujący w życiu rodzinnym, społecznym i zawodowym. Widomym znakiem respektowania tego ładu była osobista, duchowa wolność przeżywana pomimo warunków narastającego zniewolenia. Wymagało to jednak odwagi i odpowiedzialności w wymiarze osobistym i społecznym. Kardynał Wyszyński przypominał, że ważna jest umiejętność słuchania, uważność, wrażliwość na ludzkie sprawy, potrzeby duszy i ciała, ale też akceptacja drugiego człowieka z jego prawem do odmienności ${ }^{27}$. Podkreślał rolę praw człowieka, które w swej naturze są niezbywalne ${ }^{28}$ i stanowią podstawę wszelkich praw narodu, Kościoła czy państwa. Swoje rozważania odnosił do praw osobowych, społecznych, kulturalnych, politycznych oraz gospodarczych. W sposób szczególny akcentował jednak prawa człowieka jako prawa wszystkich ludzi bez względu na wiek, płeć, status materialny czy rolę społeczną. Ukazywał znaczenie Dekalogu jako zbioru praw człowieka. W omawianych przez siebie katalogach praw - ukazywał wartość prawa do życia od momentu poczęcia do naturalnej śmierci i postulował prawo do prawdy i wolności sumienia ${ }^{29}$.

24 B. Piasecki, Ostatnie dni Prymasa Tysiąclecia, Kraków 2011, s. 152.

25 S. Wyszyński, Ojcze Nasz. Rozważania, Warszawa 2001, s.72.

26 A. Fudali, Kardynał Stefan Wyszyński, Społeczny reformator, w: Społeczna potrzeba pamięci..., s. 338 i n.

27 A. Rynio, Wychowanie młodzieży w nauczaniu Stefana Kardynała Wyszyńskiego, Lublin 1995.

28 B. Piasecki, Ostatnie dni Prymasa Tysiaclecia..., s. 159-165.

29 A. Jasiński, Kardynał Stefan Wyszyński świadek wiary, cz.1, Gniezno 1999, s. 110-113. 
Po uwolnieniu z trwającego trzy lata odosobnienia w 1956 r., przez wiele lat realizował wielki program wychowania moralnego i religijnego polskiego narodu, zawarty w Wielkiej Nowennie Tysiąclecia Chrztu i obchodów Poloniae Sacrae Millenium. W programach tych nie brakowało miejsca dla wychowania patriotycznego, które miało umocnić tożsamość społeczną, doprowadzić do odrodzenia moralnego narodu i stanowiło niezbędny warunek upomnienia się przez Polaków o swoje wolności. W swoim nauczaniu ściśle łączył dzieje ojczyzny z tradycją Kościoła, a jednocześnie bardzo precyzyjnie odróżniał charyzmat wspólnoty eklezjalnej od instytucji Kościoła i rozgraniczał państwo widziane w charakterze instytucji od narodu (społeczności) ${ }^{30}$.

Zwracał uwagę na duszpasterską i patriotyczną służbę kapłanów polskich i widział nie tylko sukcesy duszpasterskie, ale równocześnie miał świadomość ogromnej odpowiedzialności kapłanów za formację społeczno-moralną dzieci i młodzieży. Razem z episkopatem wzywał wszystkich do głębokiej przemiany moralnej i zerwanie ze złem. Jako żarliwy patriota widział wyraźnie najważniejsze zagrożenia dla narodu polskiego tkwiące w niewoli duchowej i klęsce moralnej jaką jest przede wszystkim nietrzeźwość, pijaństwo, kradzieże, nieuczciwość, brak sumienności w pracy, nadużycia, szczególnie natury społecznej i publicznej. Uważał, że w wymiarze życia społeczno-moralnego najważniejszym zadaniem jest dbałość o prawe sumienie Polaków. Podkreślał przy tym wartość sumienia obywatelsko-politycznego

które nie spada z nieba, ale wypracowuje się w osobie ludzkiej, w człowieku, $\mathrm{w}$ istocie rozumnej, wolnej i miłującej, wychowanej w rodzinie posiadającej odpowiednie walory obywatelskie, społeczne, kulturalne, zawodowe oraz zrozumienie, że bonum respublicae suprema lex esto - „dobro Rzeczpospolitej jest dobrem najwyższym". Co to znaczy bonum respublicae? To znaczy dobro obywateli, dobro każdego człowieka w ojczyźnie, w narodzie. To znaczy też - prawa obywateli ${ }^{31}$.

30 J. K. Przybyłowski, Kardynał Stefan Wyszyński jako krzewiciel patriotyzmu i tradycji chrześcijańskiej w: Kardynał Stefan Wyszyński. Droga życia i posługi pasterskiej, red. R. Czekalski, Warszawa 2021, s.552.

31 S. Wyszyński, Sumienie prawe u podstaw odnowy życia narodowego, $w$ uroczystość Objawienia Pańskiego, Warszawa, Archikatedra św. Jana ,6 stycznia 1981, msps, AIPSKW; Cyt. za: J. K. Przybyłowski, Kardynał Stefan Wyszyński jako krzewiciel patriotyzmu i tradycji chrześcijańskiej w: Kardynał Stefan Wyszyński, s.560. 


\section{Podsumowanie}

Jakkolwiek analizowany temat nie został w żaden sposób wyczerpany, to patrząc na postawę Kardynała Stefana Wyszyńskiego można stwierdzić, że bardziej dbał on o swoją ojczyznę i naród niż o samego siebie. Był człowiekiem o wyjątkowo bogatej osobowości. troszcząc się o takie wychowanie patriotyczne, które by nie tylko uświadamiało prawa, ale i obowiązki względem ojczyzny, Kościoła, samego siebie i drugiego człowieka. Głosił wychowanie w duchu odpowiedzialności za naród i przyszłość całego społeczeństwa. Nakładało to szczególnie na ludzi młodych obowiązek należytego przygotowania się do przyszłego życia rodzinnego i zawodowego. Ukazując potrzebę wychowania w duchu odpowiedzialności za naród wzywał do ducha ofiary i wyrzeczenia bez których nie można mówić o dobrym spełnieniu chrześcijańskiego obowiązku. Wołając o pokolenie „nowych ludzi" zachęcał do pokonywania samolubstwa, egoizmu i wygodnictwa ${ }^{32}$. W całej duszpasterskiej działalności Prymasowi chodziło o uspołecznienie młodzieżowych ideałów religijnych, obudzenie pragnienia społecznych cnót chrześcijańskich, poznania zasad etyki społecznej i przekazania młodzieży, „że sprawiedliwość jest możliwa na świecie bez gwałtu, więzien, obozów koncentracyjnych, rozlewu krwi czy nowoczesnego niewolnictwa, wyzysku pracy ludzkiej"33.

Streszczenie: Celem publikacji było wydobycie z wielorako manifestującej się posługi duszpasterskiej kardynała Stefana Wyszyńskiego specyfiki jego poglądów dotyczących wychowania patriotycznego dzieci i młodzieży. W pierwszej części publikacji próbowano przybliżyć prymasowski sposób rozumienia samego zjawiska patriotyzmu. Przybliżając i prezentując jego poglądy, wskazano nie tylko na istotne elementy konstytuujące patriotyzm widziany tu w kategorii aksjologicznej (pożądana wartość), psychologicznej (postawa), ale działaniowej (wychowanie). Odpowiedzialnemu wychowaniu patriotycznemu dzieci i młodzieży poświęcono drugą część publikacji. Dokonane analizy pozwoliły nie tylko zgłębić ten jakże ważny problem, ale dały możliwość dokonania pewnych uogólnień w formie przyjętych wniosków i podsumowań.

Okazało się, że w myśl poglądów Stefana Wyszyńskiego, patriotyzm stanowi cenną wartość w życiu każdego człowieka i należy nań patrzeć raczej przez pryzmat powinności, a nie przywileju. Powinność ta ma na celu miłowanie własnej ojczyzny i kształ-

32 S. Wyszyński, Idącym w przyszłość, Warszawa 1989; S. Wyszyński, Problem chrześcijańskiego wychowania młodzieży, „Zeszyty Naukowe KUL”, 1969, nr 2.

33 Listy Pasterskie Prymasa Polski 1946-1974, Paryż 1975, s. 130. 
towanie poczucia tożsamości narodowej. Wyszyński nawołuje do odpowiedzialności za proces wychowania patriotycznego, w którym ważne jest pielęgnowanie ojczystej mowy, szacunek do dziedzictwa narodowego oraz dbałość o prawdę i przekaz niezafałszowanej historii. Istotnym zadaniem, które było wyrazem spełniania obowiązku poczucia odpowiedzialności za naród jest troska o życie każdego obywatela, nie wyłączając dzieci nienarodzonych, i obrona wartości narodowych i chrześcijańskich. Publikacja uświadamia, że prymasowskie rozumienie patriotyzmu podobnie jak i wychowania warunkowane było nie tylko jego doświadczeniem osobistym, wyniesionym z domu rodzinnego i ze szkoły, ale było zależne od przyjmowanej antropologii i bogatej wiedzy socjologiczno-historycznej, a także umiejętności osądu i doświadczenia pedagogicznego. Rozumienie to dalekie było od nacjonalizmu czy nietolerancji dla kogokolwiek. Wyrastało ono z wierności Bogu, człowiekowi, wielowiekowej tradycji i kulturze chrześcijańskiej. Gwarantowało dążenie do prawdy, wolności, poszanowania praw ludzkich, prawości w myśleniu i działaniu, tożsamości i trwania narodu.

Słowa kluczowe: Kardynał Stefan Wyszyński, patriotyzm, ojczyzna, naród, wychowanie patriotyczne, działalność duszpasterska.

\section{Bibliografia}

Bartnik Cz., Pedagogika narodowa Prymasa Stefana Wyszyńskiego, Lublin 2001.

Fudali A., Kardynał Stefan Wyszyński, Społeczny reformator, w: Społeczna potrzeba pamięci. Osoba i dzieło Kardynała Stefana Wyszyńskiego Prymasa Tysiaclecia, red. A. Rynio, M. Parzyszek, Lublin 2017, s. 337-341.

Gronkowska A., Po Bogu Polska była dla Niego... w: Społeczna potrzeba pamięci. Osoba i dzieło Kardynała Stefana Wyszyńskiego Prymasa Tysiąclecia, red. A. Rynio, M. Parzyszek, Lublin 2017, s. 359-362.

Jasiński A., Kardynał Stefan Wyszyński świadek wiary, cz. 1. Gniezno 1999.

Kardynał Stefan Wyszyński. Drogi życia i posługi pasterskiej, red. R. Czekalski, Warszawa 2021.

Kardynał Stefan Wyszyński, Kruszwica, kościół śś. Piotra i Pawła, 18 września 1970.

Kijas Z. J., Wyszyński. Narodziny nowego człowieka, Warszawa 2021.

Kowalczyk A. M., Ethos Katolickiego Uniwersytetu Lubelskiego w wypowiedziach Kardynała, w: Społeczna potrzeba pamięci. Osoba i dzieło Kardynała Stefana Wyszyńskiego Prymasa Tysiaclecia, red. A. Rynio, M. Parzyszek, Lublin 2017, s. 283-293.

Kowalczyk S. Personalizm społeczno-aksjologiczny Kardynała Stefana Wyszyńskiego, w: Społeczna potrzeba pamięci. Osoba i dzieło Kardynała Stefana Wyszyńskiego Prymasa Tysiąclecia, red. A. Rynio, M. Parzyszek, Lublin 2017s. 125-134.

Listy Pasterskie Prymasa Polski 1946-1974, Paryż 1975. 
Niezwykły gość. Ksiądz Stefan Wyszyński u Aleksandra i Jadwigi Zamoyskich w Kozłówce, Muzeum Zamoyskich w Kozłówce 2021.

Ojciec Święty Jan Paweł II o Kardynale Stefanie Wyszyńskim, w: Człowiek niezwykłej miary, Warszawa 1984, s. 127-140.

Parzyszek M., Rodzina w nauczaniu Stefana Wyszyńskiego, w: Społeczna potrzeba pamięci. Osoba i dzieło Kardynała Stefana Wyszyńskiego Prymasa Tysiąclecia, red. A. Rynio, M. Parzyszek, Lublin 2017, s. 221-235.

Piasecki B., Ostatnie dni Prymasa Tysiąclecia, Kraków 2011.

Przybyłowski J. K., Kardynał Stefan Wyszyński jako krzewiciel patriotyzmu i tradycji chrześcijańskiej, w: Kardynał Stefan Wyszyński. Droga życia i posługi pasterskiej, red. R. Czekalski, Warszawa 2021, s.547-563

Rastawicka A., Maryjne drogi wolności Prymasa Tysiąclecia. Czytania majowe, Warszawa 2018.

Rynio A., Mądre wychowanie patriotyczne przedmiotem troski Prymasa Tysiąclecia, „Studia Prymasowskie” 5 (2011), s. 247-264.

Rynio A., Myśl pedagogiczna Stefana Kardynała Wyszyńskiego, w: Kardynał Stefan Wyszyński (1901-1981) Myśl społeczna, red.S. Fel, M. Wódka, Lublin 2017, s. 47-70.

Rynio A., Idea Narodu i odpowiedzialności za naród w kazaniach milenijnych czcigodnego Sługi Bożego Kardynała Stefana Wyszyńskiego, Lublin 2020.

Rynio A., Wychowanie młodzieży w nauczaniu Stefana Kardynała Wyszyńskiego, Lublin 1995.

Rynio A., Wychowanie patriotyczne w nauczaniu Sługi Bożego Kardynała Stefana Wyszyńskiego, w: Prymas Wyszyński a Niepodległa: naród - patriotyzm - państwo w nauczaniu Prymasa Tysiąclecia, red. Ewa K. Czaczkowska, Rafał Łatka, Warszawa 2019, s. 105-120.

Stępień M. B., Kościół i Naród jako wartości fundamentalne, w: Prymas Tysiąclecia w komunistycznym państwie, red. Z. Zieliński, Radom 2003, s. 9-31.

Wyszyński S., Po Polaków i Polonii, Warszawa 2020.

Wyszyński S., Idącym w przyszłość, Warszawa 1989.

Wyszyński S., Jedna jest Polska, Warszawa 1998.

Wyszyński S., Ojcze Nasz. Rozważania, Warszawa 2001.

Wyszyński S., Problem chrześcijańskiego wychowania młodzieży, „Zeszyty naukowe KUL” 1969, nr 2.

Wyszyński S., Sumienie prawe u podstaw odnowy życia narodowego, w uroczystość Objawienia Pańskiego, Warszawa, Archikatedra św. Jana, 6 stycznia 1981, msps, AIPSKW. 